\title{
The blood picture in the guinea-pig in acute and chronic scurvy
}

\author{
By B. J. CONSTABIE \\ Dunn Nutritional Laboratory, University of Cambridge and Medical Research Council
}

$$
\text { (Received } 27 \text { November I958-Revised I8 March 1960) }
$$

For many years anaemia has been considered to be part of the syndrome of scurvy. Various investigators have reported finding anaemia in vitamin $\mathrm{C}$ deficiency, both in human beings (Parsons \& Smallwood, 1935; Jennings \& Glazebrook, 1938; Vilter \& Woolford, 1945; Vilter, Woolford \& Spies, 1946; Israëls, 1943; Bronte-Stewart, r953) and in guinea-pigs (Mettier \& Chew, I932; Aron, 1939; Sigal, r939; Desmarais \& McCraw, 1956). Some workers claimed that the anaemia in human subjects could be corrected by the administration of vitamin C (Jennings \& Glazebrook, 1938; Vilter \& Woolford, I945; Vilter et al. 1946; Bronte-Stewart, I953; Israëls, 1943), but others found no response (Lozner, I94I; Liu, Chu, Yu, Hsu \& Cheng, 194I). In guinea-pigs, Aron (1939) corrected anaemia with vitamin C. Bartley, Krebs \& O'Brien (1953) and Crandon, Lund \& Dill (1940) failed to produce anaemia in experimental vitamin $\mathrm{C}$ deficiency in human subjects.

Thus, although much work has been carried out on this subject the position is still obscure. It seems possible that the divergent results reported in the past have been the result of varying experimental conditions. In many of the experiments reported, both with human subjects and with guinea-pigs, nutritional deficiencies other than of vitamin $\mathrm{C}$ appear to have been present. An examination of the diets, the age of the experimental animals, the time taken for scurvy to develop, and, when human beings were used, the often unavoidably unsatisfactory type of subject, seems to support this view.

Crandon et al. (1940), who carried out a carefully controlled experiment on a human subject, found that in spite of frequent withdrawals of blood for examination, involving a total loss of $6000 \mathrm{ml}$ throughout the experiment, no sign of anaemia was apparent after 6 months on a scorbutogenic diet. Bartley et al. (1953) reported that human volunteers, after 8 months on a scorbutogenic diet, with definite signs of vitamin $C$ deficiency, had normal haemoglobin levels and red-cell counts. These two experiments are among the few where carefully controlled vitamin $\mathrm{C}$ deficiency has been produced in the human subject.

In many guinea-pig experiments the diets used have been unsatisfactory, either because of their deficiency in various growth factors, or because of the possible presence of vitamin C. When a satisfactory semi-synthetic diet for guinea-pigs (Reid \& Briggs, 1953) became available, a re-examination of the blood picture in guinea-pig scurvy seemed likely to prove of value in solving the problem of the connexion (if any) between anaemia and scurvy. The present paper describes such an investigation. 


\section{EXPERIMENTAL}

Animals. Male albino guinea-pigs, obtained from Allington Farm, Ministry of Supply, Porton, Wilts., were used in all the experiments. The animals weighed about $250 \mathrm{~g}$ each, and were at once put on the standard diet (see below) with ascorbic acid added at the rate of $0.2 \%$ of the diet, supplying on the average about $60 \mathrm{mg}$ ascorbic acid/guinea-pig/day. On reaching $300 \mathrm{~g}$ body-weight, the animals were divided into groups, the control animals being kept on the same diet, whereas those in the deficient groups had the diet without the added ascorbic acid. In Expt 4, older guinea-pigs were obtained from the same source, and placed on experiment at about $500 \mathrm{~g}$ body-weight.

Diet. The basal scorbutogenic diet used in these experiments was essentially that recommended by Reid \& Briggs (r953), and its composition is given in Table $\mathbf{I}$.

Blood volume. Plasma volume was estimated by the dye technique. The dye used was Evans's blue 'Tr824 (Dawson, Evans \& Whipple, 1920), since it is known to be eliminated only very slowly from the blood stream (Gregerson \& Rawson, 1943). The dye was injected from a micrometer syringe into the exposed right external jugular veins of the guinea-pigs, which were under deep diethyl-ether anaesthesia. The abdominal cavity and thorax were opened to expose the inferior vena cava and, $4 \mathrm{~min}$ after the injection of the dye, about $5 \mathrm{ml}$ of blood were rapidly aspirated into a syringe containing about 100 i.u. heparin. The content of the blue dye in the plasma was estimated by precipitation of the dye as described by Constable (1958). With the aid of the haematocrit determination the total blood volume was calculated.

Haemoglobin. Haemoglobin $(\mathrm{Hb})$ was estimated by the alkaline-haematin method (Wu, 1922), the final colour being measured in a photoelectric colorimeter fitted with a Wratten $6 \mathrm{r}$ N filter, maximum transmission $520 \mathrm{~m} \mu$. Crystalline haemin was used in the preparation of the standard.

Red blood cell count. Red blood cell counts (R.B.C.C.) were made in the improved Neubauer ruling counting chamber, with Hayem's solution as the diluting medium. A standard red-cell pipette was used in the preparation of the sample. Red-cell counts showed a variation of $\pm 5 \%$ on a single blood sample.

Haematocrit. The packed-cell volume (P.c.v.) determinations were carried out in Wintrobe tubes, which were centrifuged for $30 \mathrm{~min}$ at $1600 \mathrm{~g}$. An allowance of $3 \%$ of the P.c.v. was made for trapped plasma. This value was taken from the work of Chaplin \& Mollison (1952) as being an average one for a P.c.v. of approximately $40 \%$.

Reticulocytes. Reticulocyte smears were prepared by placing a drop of blood on a dried film of brilliant cresyl blue, and counterstaining with Leishman's stain, the reticulocytes being counted differentially against a minimum count of Iooo red cells.

Design of experiments. Six separate experiments were carried out, involving 127 guinea-pigs.

The aims of the experiments were to try to find answers to the following questions.

(I) In the guinea-pig, is anaemia concomitant with scurvy; if it is, is the anaemia due $(a)$ to defective functioning of the bone marrow, or $(b)$ to the rapid loss of blood caused by internal haemorrhages such as those that occur, for example, in the tissues round the knee joints? 
(2) Does the age of the animal, or the time taken for scurvy to develop, influence the degree of anaemia?

(3) What happens to the blood picture in chronic scurvy (partial deficiency of vitamin $\mathrm{C})$ ?

(4) Do changes in blood volume occur in scurvy?

The lay-out of the experiments is shown in Table 2.

\section{Table 1. Composition of basal diet}

$\begin{array}{lclc} & \begin{array}{c}\text { Parts } \\ \text { by weight }\end{array} & \text { Maize oil } & \begin{array}{c}\text { Parts } \\ \text { by weight }\end{array} \\ \text { Sucrose } & \text { 103 } & \text { Casein } & 73 \\ \text { Glucose } & 78 & \text { Cellophane (flaked film)† } & 300 \\ \text { Salt mixture* } & 60 & \text { Ascorbic acid } \ddagger & \text { I50 } \\ \text { Maize starch } & 200 & \text { B vitamins\$ } & \text { See below } \\ \text { Potassium acetate } & 25 & \text { Fee below } \\ \text { Magnesium oxide } & 5 & \text { Fat-soluble vitamins } & \text { See below } \\ \text { Inositol } & 2 & & \end{array}$

* Parts (by weight): sodium chloride 50 , calcium phosphate $\left(\mathrm{Ca}_{3}\left(\mathrm{PO}_{4}\right)_{2}\right)_{4} 00$, iron citrate 35, potassium iodide $\mathrm{I}$, magnesium sulphate 80 , sodium phosphate $\left(\mathrm{NaH}_{2} \mathrm{PO}_{4} \cdot 2 \mathrm{H}_{2} \mathrm{O}\right){ }_{13} \cdot 5$, potassium chloride 250, sodium fluoride 0.04 , manganese sulphate 0.2 , cupric sulphate 0.34 , zinc carbonate 0.34 .

$\dagger$ Obtained from British Cellophane Ltd, Bridgewater, Somerset.

\pm Diets for the positive controls were made up as above, but with the addition of ascorbic acid at the rate of $0.2 \%$ of the diet.

$\S$ Dissolved in $20 \mathrm{ml}$ water and added to $\mathrm{I} \mathrm{kg}$ of the diet, during its preparation; thiamine hydrochloride 16 , riboflavin 16 , pyridoxine hydrochloride 16 , calcium pantothenate 40 , vitamin $B_{12}$ (Cytamen 100, Glaxo Laboratories Ltd) 0.05 , nicotinamide 200 , folic acid 10 , biotin ${ }^{\cdot} \cdot \mathbf{z} \mathrm{mg}$ and choline chloride $\mathbf{2 g}$.

II Supplements were given to all animals twice weekly, as follows: vitamin E ( $\alpha$-tocopheryl acetate), $5 \%(w / w)$ in arachis oil, two drops; halibut-liver oil, two drops; vitamin $\mathrm{K}$ (menaphthone), $5 \%(\mathrm{w} / \mathrm{w})$ in arachis oil, two drops.

\section{Table 2. Plan of experiment}

\begin{tabular}{|c|c|c|c|c|}
\hline $\begin{array}{l}\text { Expt } \\
\text { no. }\end{array}$ & $\begin{array}{l}\text { Group } \\
\text { no. }\end{array}$ & Diet & $\begin{array}{l}\text { Weight of } \\
\text { animals at } \\
\text { beginning } \\
\text { of } \\
\text { experiment } \\
\text { (g) }\end{array}$ & $\begin{array}{l}\text { Ascorbic-acid } \\
\text { intake }\end{array}$ \\
\hline $1,2,3$ & $\begin{array}{l}\mathbf{I} \\
\mathbf{2}\end{array}$ & $\begin{array}{l}\text { Deficient } \\
\text { Sufficient, pair- } \\
\text { fed with } \\
\text { group I }\end{array}$ & $\begin{array}{l}300 \\
300\end{array}$ & $0.2 \% \stackrel{\circ}{\circ}$ of diet \\
\hline & 3 & Sufficient, ad lib. & 300 & $0.2 \%$ of diet \\
\hline 4 & $\begin{array}{l}\mathbf{I} \\
\mathbf{2}\end{array}$ & $\begin{array}{l}\text { Deficient } \\
\text { Sufficient, } \\
\text { pair-fed with } \\
\text { group I }\end{array}$ & $\begin{array}{l}500 \\
500\end{array}$ & $0.2 \%$ of diet \\
\hline & 3 & Sufficient, ad lib. & 500 & $0.2 \%$ of diet \\
\hline 5 & $\begin{array}{l}\mathbf{I} \\
\mathbf{2}\end{array}$ & $\begin{array}{l}\text { Deficient } \\
\text { Deficient }\end{array}$ & $\begin{array}{l}300 \\
300\end{array}$ & $\begin{array}{l}0.4 \mathrm{mg} \text { daily } \\
6.4 \mathrm{mg} \text { daily }\end{array}$ \\
\hline 6 & $\begin{array}{l}I \\
2\end{array}$ & $\begin{array}{l}\text { Deficient } \\
\text { Sufficient }\end{array}$ & $\begin{array}{l}300 \\
300\end{array}$ & $0.2 \%$ of diet \\
\hline
\end{tabular}

Aim of experiment

To ascertain if anaemia develops in acute scurvy (avitaminosis) in young animals

To ascertain if anaemia develops in acute scurvy in older animals

To ascertain if anaemia develops in chronic scurvy (hypovitaminosis)

To ascertain if bone-marrow function is stimulated in scurvy and how blood volume is affected 
In the first three experiments, guinea-pigs of $300 \mathrm{~g}$ body-weight, kept on a diet completely free from vitamin $\mathrm{C}$, were compared (I) with a group of positive controls kept on an exactly similar diet but with $0.2 \%$ of ascorbic acid added, and (2) with another group of controls receiving this second diet, but with their food intake restricted to that eaten by the first group (pair-fed controls). The animals in the deficient groups were killed for haematological examination when their food intake had fallen to almost nothing, and when their body-weights indicated that they could be expected to die in 1 or 2 days. Individual animals in the control and pair-fed groups were linked with corresponding animals in the deficient group, and killed on corresponding days.

Expt 4 repeated the conditions of Expts r, 2 and 3, with the one exception that older guinea-pigs (500-600 g) were used. It has been suggested (Desmarais \& McCraw, I956) that young guinea-pigs are more prone to infection during the development of scurvy than are half-grown animals of about $500 \mathrm{~g}$ body-weight, and that death occurs in them before the anaemia has had time to develop.

In Expt 5 the guinea-pigs were kept on controlled intakes of ascorbic acid for fairly long periods, and then killed. The levels of ascorbic-acid intake were $0.4 \mathrm{mg} / \mathrm{animal}$ daily (suboptimal) and $6.4 \mathrm{mg} /$ animal daily (fully adequate).

Expt 6 was similar to Expts 1, 2 and 3 with the exception that reticulocyte counts and blood volumes were determined.

\section{RESULTS}

Fig. I shows typical growth curves for groups of deficient, pair-fed and 'ad lib.' animals. For the first ro days, the growth was the same in all groups, but after this time the animals on the diet without ascorbic acid lost weight and died after a further IO-I 2 days. The pair-fed group lost weight at a much slower rate. The animals receiving the diet ad lib. showed a continuous gain in weight, averaging $6.5 \mathrm{~g} /$ day, and after 20-22 days on experiment were about twice the weight of those in the deficient group.

In Table 3 a comparison of the blood picture of deficient, pair-fed and 'ad lib.' 2-month-old guinea-pigs, from the first three experiments, is given. There was no significant difference between the deficient and 'ad lib.' animals. An increase in the P.C.v., $\mathrm{Hb}$ and R.B.c.c. was observed in the pair-fed groups.

Table 4 gives the results of Expt 4. As in the experiments with younger guinea-pigs, the deficient and 'ad lib.' groups showed no statistical difference in P.c.v., Hb or R.B.C.C. The values for the pair-fed group were only slightly higher in this experiment.

In Table 5 the results are given of Expt 5. In this experiment the group receiving $0.4 \mathrm{mg}$ ascorbic acid daily developed chronic scurvy, and increases in P.c.v., $\mathrm{Hb}$ and R.B.C.c. were noted. These increases in the chronic-scurvy group were very similar to those in the pair-fed groups (Table 3).

Table 6 gives details of another experiment with 2-month-old guinea-pigs. There was no change in the P.C.v., $\mathrm{Hb}$ or R.B.c.c. (as was likewise noted in Table 3), but in this experiment reticulocyte counts were made and the blood volumes determined. An increase of about $400 \%$ in the reticulocytes was found in the deficient group. 


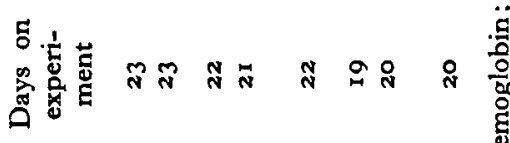

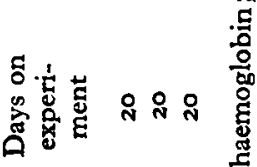

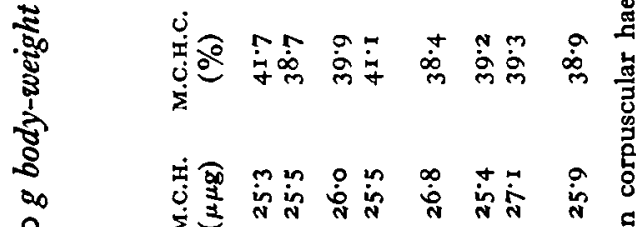

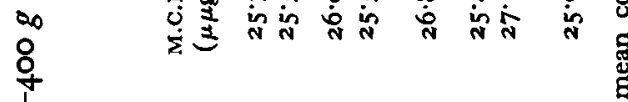

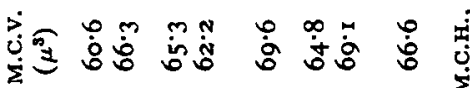

के मे

(2)

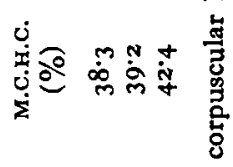

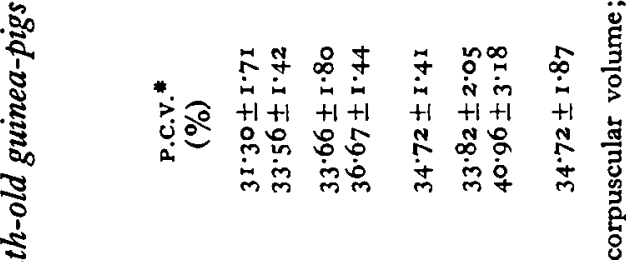

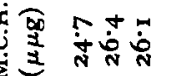

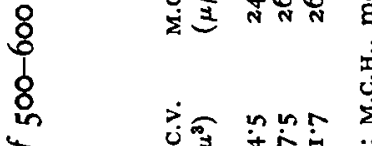

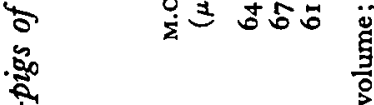

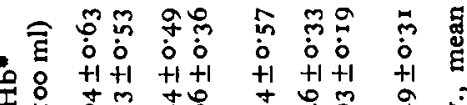

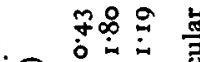

웅 $+1+1+1$

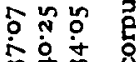

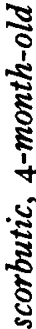

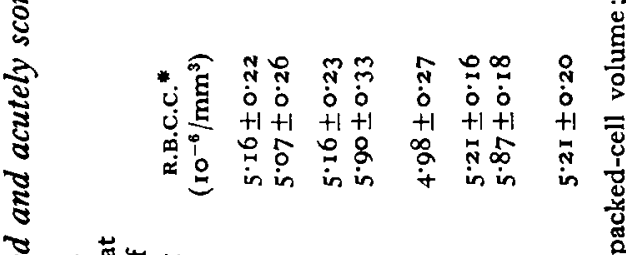

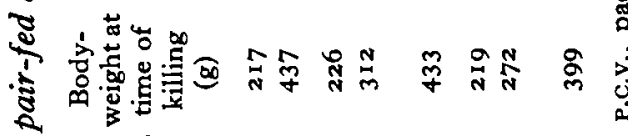

ฐูป

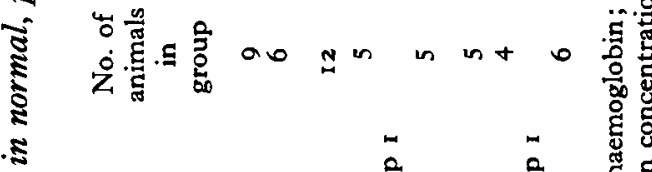

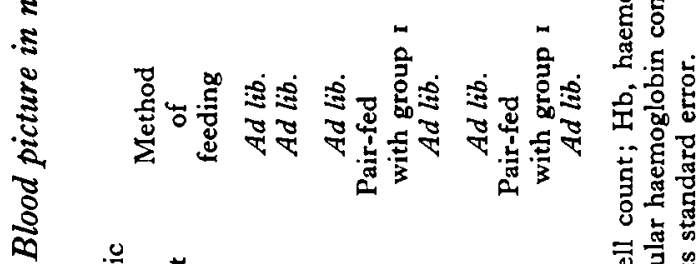

苟

穴

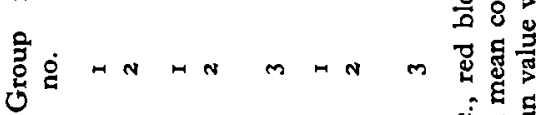

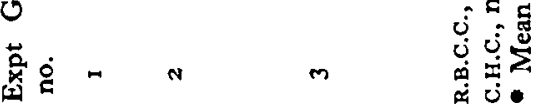

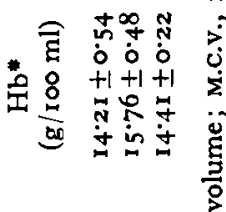

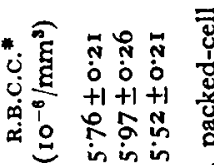

Tับ

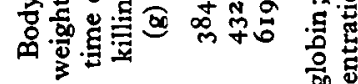

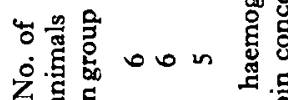

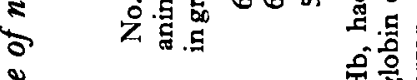

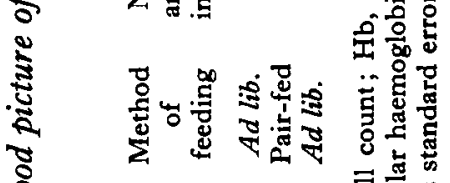

\$)

告

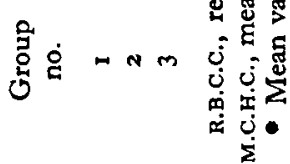




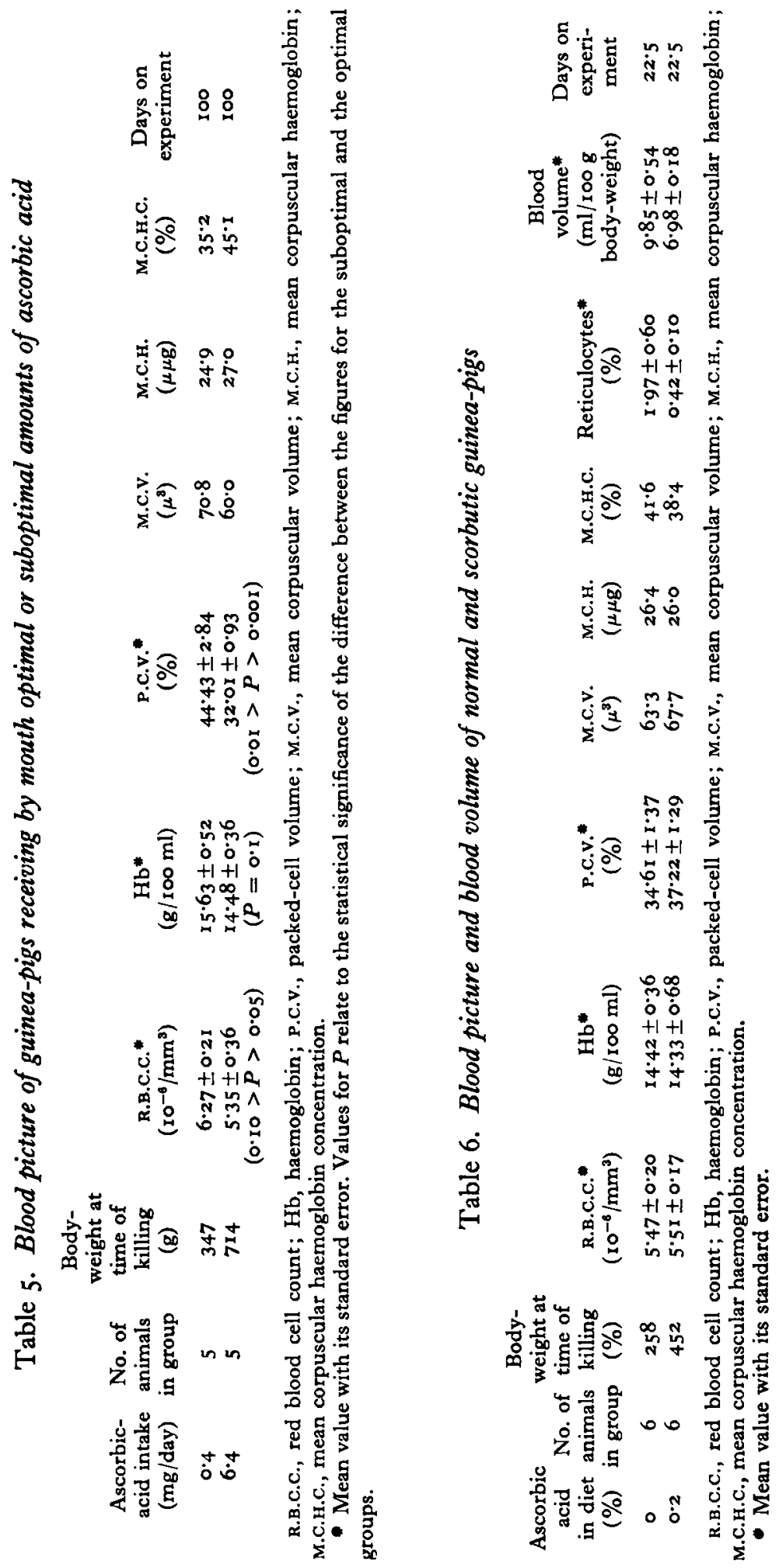


A decrease of about $2 \mathrm{x} \%$ in the total blood volume, and an increase of $39 \%$ in the blood volume per roo $\mathrm{g}$ body-weight, were also noted in this group.

In Table 7 a comparison is given of the total circulating Hb, P.c.v. and R.B.C.C. between the deficient and control groups. When expressed per roo $\mathrm{g}$ body-weight the values were higher in the deficient group, but when expressed as total per animal those of the control group were significantly higher.

During the experiments all guinea-pigs in groups deficient in vitamin $\mathrm{C}$ developed extensive haemorrhages in the tissues round the knee joints.

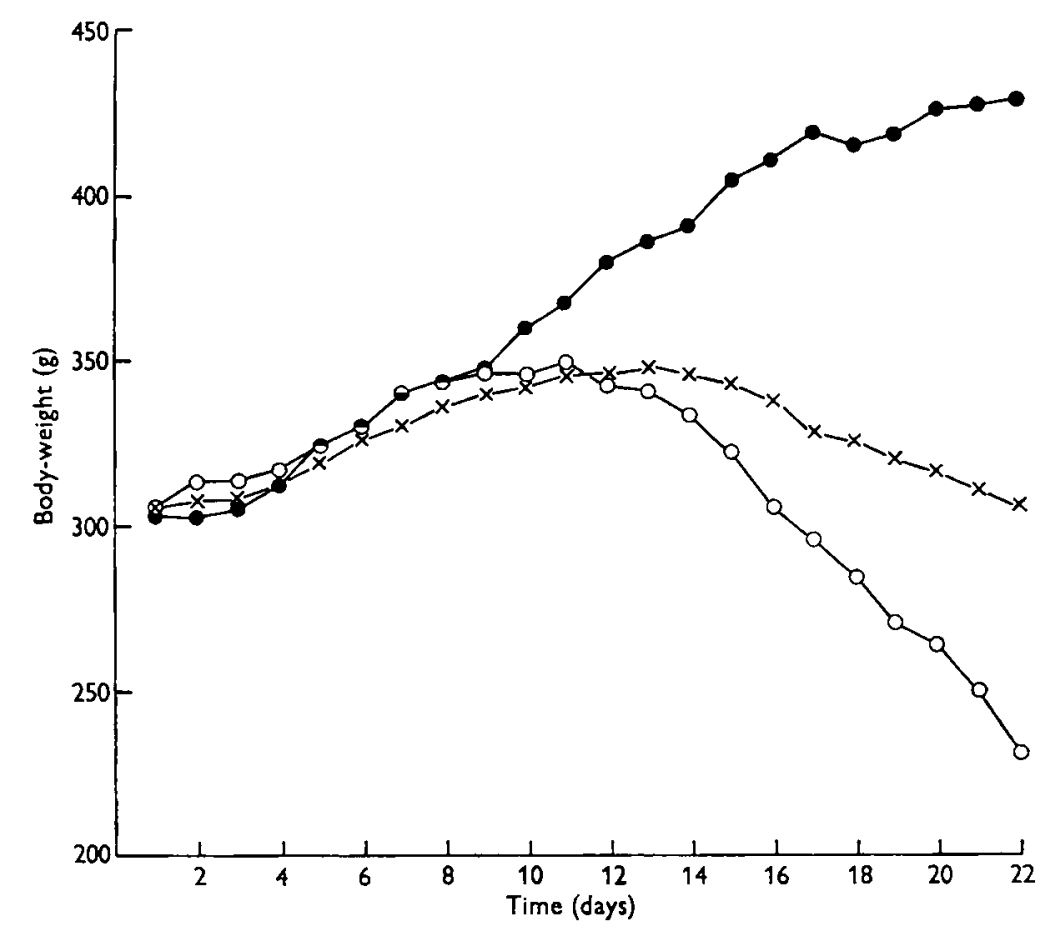

Fig. I. Expt I. Mean weight curves of groups of guinea-pigs (six animals/group). $\circ-0$, scorbutic group; $\times \longrightarrow \times$, pair-fed group; $\longrightarrow$, positive control group.

Table 7. Circulating haemoglobin, red-cell count and packed-cell volume of normal and scorbutic guinea-pigs

$\begin{array}{cccccccc}\begin{array}{c}\text { Ascorbic } \\ \text { acid } \\ \text { in diet } \\ (\%)\end{array} & \begin{array}{c}\text { No. of } \\ \text { animals } \\ \text { in group }\end{array} & \begin{array}{c}\text { R.B.c.c. } \\ \left(\times 10^{-10}\right)\end{array} & \begin{array}{c}\text { Hb } \\ (\mathrm{g})\end{array} & \begin{array}{c}\text { P.c.v. } \\ (\mathrm{ml})\end{array} & \overbrace{\begin{array}{c}\text { R.B.c.c. } \\ \left(\times 10^{-10}\right)\end{array}}^{\text {Per } 100 \mathrm{~g} \text { body-weight }} & \begin{array}{c}\text { Hb } \\ (\mathrm{g})\end{array} & \begin{array}{r}\text { P.v.c. } \\ (\mathrm{ml})\end{array} \\ 0 & 6 & 5.38 & 1.42 & 3.41 & 13.90 & 3.66 & 8.80 \\ 0.2 & 6 & 3.84 & 1.00 & 2.60 & 17.37 & 4.52 & 11 \cdot 75\end{array}$

R.B.C.C., red blood cell count; Hb, haemoglobin; P.C.v., packed-cell volume. 


\section{DISCUSSION}

\section{Vitamin C deficiency without anaemia}

Anaemia has been defined as 'a reduction below normal in the number of red corpuscles per $\mathrm{cmm}$., the quantity of haemoglobin, and the volume of packed red cells per 100 cc. of blood' (Wintrobe, I946). Judged by this definition, these experiments have shown that guinea-pigs do not develop anaemia when fed on a diet deficient in ascorbic acid but containing adequate quantities of other vitamins and nutrients. In guinea-pigs completely deprived of ascorbic acid for 20-22 days, the P.c.v., R.B.C.C. and $\mathrm{Hb}$ concentration were not significantly different from those of normal controls.

It may be noted that the guinea-pigs were kept on the scurvy-producing diet for only 20-22 days, and were presumably not showing signs of vitamin $\mathrm{C}$ deficiency until half-way through this period, when the loss of body-weight began. If it is assumed that the life-span of the guinea-pig erythrocyte is 83 days, as suggested by Everett $\&$ Yoffey (1959), it is perhaps not surprising that no notable changes in the blood picture occurred within this short period. Nevertheless, it does seem significant that any loss of haemoglobin and erythrocytes, from the haemorrhages that were invariably present by the end of the experiment in the deficient guinea-pigs, appears to have been made good.

An increase was noted in the blood volume per unit body-weight in the scorbutic animals when compared with normal controls of the same age. However, there was no difference when the comparison was with normal animals of the same weight, the percentage blood volume being higher in smaller animals (Constable, unpublished). Although the concentration of Hb, P.C.V. and R.B.C.c. in the blood were unchanged, the total amounts per animal were significantly decreased in the deficient guinea-pigs ('Table 7).

An increase in the number of reticulocytes of up to $400 \%$ was observed in the vitamin C-deficient animals. The reason for the increase might be a shortened life-span of the erythrocyte, but the most likely explanation may be that the chronic haemorrhages which occurred in the animals were stimulating an increased blood production. 'In anaemia due to acute blood loss an orderly rise of reticulocytes occurs in the circulating blood' (Minot \& Castle, 1935).

\section{Effect of restricted food intake}

Guinea-pigs in the pair-fed groups differed considerably from the normal controls; the P.C.v., $\mathrm{Hb}$ and the R.B.C.c. were all increased. These results are in agreement with those of other workers who investigated inanition in the rat (Shukers \& Day, 1943; Widdowson \& McCance, 1956).

\section{Limited intake of vitamin $C$}

Guinea-pigs kept on a diet containing a suboptimal allowance of ascorbic acid $(0.4 \mathrm{mg} /$ day $)$ for I00 days in order to produce chronic hypovitaminosis as distinct 
from avitaminosis showed no anaemia. On the contrary, if anything, there were slight increases in P.C.v., R.B.c.c. and $\mathrm{Hb}$ levels, similar to those that occurred in the pair-fed controls to the 'completely deficient' group.

As the duration of this experiment was 100 days, which is longer than the life-span of the erythrocyte (Everett \& Yoffey, 1959), it may now be regarded as established that hypovitaminosis $\mathrm{C}$ at any rate does not produce anaemia in the guinea-pig. The animals restricted to the suboptimal intake of vitamin $\mathrm{C}$ gained very little weight throughout the experiment, and the small increase in R.B.c.C., P.C.v. and $\mathrm{Hb}$ may perhaps be related to a lowered food intake, as these changes were found to occur also in the pair-fed controls to the deficient ('avitaminosis') group.

\section{Import of other factors}

Failure to find anaemia in scorbutic guinea-pigs is surprising in view of the many reports (Mettier \& Chew, 1932; Aron, I939; Sigal, 1939; Desmarais \& McCraw, 1956) that anaemia does occur. The experiments described in this paper have differed, however, from those of most other workers in that the scorbutogenic diet contained adequate amounts of other known vitamins, minerals and other nutrients (apart from ascorbic acid). It is possible that the diets used by other workers contained marginal amounts of nutrients essential for erythropoiesis, and that the scorbutic state may have produced a conditioned deficiency of one or more of these factors. The view expressed by Desmarais \& McCraw (1956), that the age of the animal was important in determining whether or not anaemia developed, could not be confirmed: in contrast to their results, no anaemia was found in half-grown animals. Further work is obviously needed to establish whether some combination of other factors may be necessary for the production of anaemia in scurvy. In this connexion, the apparent interrelations between folic, folinic, ascorbic and dehydroascorbic acids may be borne in mind.

\section{SUMMARY}

I. Guinea-pigs of $300 \mathrm{~g}$ or $500-600 \mathrm{~g}$ body-weight were fed on a semi-synthetic diet containing the known vitamins with the exception of vitamin C. Control and pair-fed groups of animals of the same body-weight were fed on the same diet with vitamin $\mathrm{C}$, at the rate of $0.2 \%$ of the diet.

2. The guinea-pigs receiving the diet without vitamin $\mathrm{C}$ developed acute scurvy in 20-22 days. These animals showed no sign of anaemia, as judged by there being no significant difference between the packed-cell volume, haemoglobin and red blood cell counts of the animals in this group and of those in the control group given vitamin $\mathrm{C}$.

3. The animals in the pair-fed groups receiving vitamin $\mathrm{C}$ showed some increase in P.C.v., $\mathrm{Hb}$ and R.B.C.C. over those in the control groups.

4. An increase in reticulocytes occurred in the deficient animals.

5. The blood volume expressed as percentage of body-weight was found to be increased in the deficient animals, but the total blood volume was decreased.

6. A further group of guinea-pigs was restricted to a suboptimal intake of vitamin $\mathrm{C}$, namely $0.4 \mathrm{mg} /$ day for 100 days, in order to produce chronic scurvy (i.e. hypovita- 
minosis, as distinct from acute avitaminosis). The animals in this group ceased gaining weight, but $\mathrm{Hb}$, P.C.v. and R.B.c.c. were not diminished.

7. It is concluded that guinea-pigs fed on a diet deficient in ascorbic acid, but containing adequate amounts of other vitamins and nutrients, do not develop anaemia.

I thank Mrs D. H. Heard of the Department of Medicine, Cambridge, for advice and helpful suggestions during the investigation, and Professor L. J. Witts and Dr F. G. J. Hayhoe for having kindly read and criticized the text.

\section{REFERENCES}

Aron, H. C. S. (1939). F. Nutr. 18, 375 .

Bartley, W., Krebs, H. A. \& O’Brien, J. R. P. (1953). Spec. Rep. Ser. med. Res. Coun., Lond., no. 280. Bronte-Stewart, B. (1953). Quart. F. Med. 87, 309.

Chaplin, H. \& Mollison, P. L. (1952). Blood, 7, 1227.

Constable, B. J. (1958). Clin. Sci. 17, 597.

Crandon, J. H., Lund, C. C. \& Dill, D. B. (1940). New Engl. F. Med. 223, 354.

Dawson, A. B., Evans, H. M. \& Whipple, G. H. (1920). Amer. F. Physiol. 51, 232.

Desmarais, A. \& McCraw, J. Y. (1956). Rev. canad. biol. 14, 322.

Everett, N. B. \& Yoffey, J. M. (1959). Proc. Soc. exp. Biol., N.Y., 101, 318.

Gregerson, M. I. \& Rawson, R. A. (1943). Amer. F. Physiol. 138, 698.

Israëls, M. C. G. (1943). Lancet, 244, 170 .

Jennings, G. H. \& Glazebrook, A. J. (1938). Brit. med. F. ii, 784.

Liu, S. H., Chu, H. I., Yu, T. F., Hsu, H. C. \& Cheng, T. Y. (I94I). Proc. Soc. exp. Biol., N.Y., 46, 603 .

Lozner, L. E. (194I). New Engl. F. Med. 224, 265.

Mettier, S. R. \& Chew, W. B. (1932). F. exp. Med. 55, 97 r.

Minot, G. R. \& Castle, W. B. (1935). Lancet, 229, 3 I 9.

Parsons, L. G. \& Smallwood, W. C. (1935). Arch. Dis. Childh. 1o, 327.

Reid, M. E. \& Briggs, G. M. (I953). F. Nutr. 51, 341.

Shukers, C. F. \& Day, P. L. (1943). F. Nutr. 25, 5 I 1.

Sigal, A. (1939). Proc. Soc. exp. Biol., N.Y., 42, 163.

Vilter, R. W. \& Woolford, R. M. (1945). F. Lab. clin. Med. 30, 388.

Vilter, R. W., Woolford, R. M. \& Spies, T. D. (1946). F. Lab. clin. Med. 3r, 609.

Wertman, K., Rotundo, R. \& Yee, R. (1953). F. Nutr. 50, 479.

Widdowson, E. M. \& McCance, R. A. (1956). Brit. F. Nutr. 1o, 363.

Wintrobe, M. M. (1946). Clinical Haematology, and ed., p. 285. London: Henry Kimpton.

Wu, H. (1922). F. Biochem., Tokyo, 2, 173. 